Canadian University Music Review

Canadian University Music Review

Revue de musique des universités canadiennes

\title{
Post-Positivistic Educational Thought: Implications for Naturalistic Research Methods in School Music
}

\section{Carol E. Harris}

Volume 12, numéro 1, 1992

URI : https://id.erudit.org/iderudit/1014211ar

DOI : https://doi.org/10.7202/1014211ar

Aller au sommaire du numéro

\section{Éditeur(s)}

Canadian University Music Society / Société de musique des universités canadiennes

ISSN

0710-0353 (imprimé)

2291-2436 (numérique)

Découvrir la revue

Citer cet article

Harris, C. E. (1992). Post-Positivistic Educational Thought: Implications for Naturalistic Research Methods in School Music. Canadian University Music Review / Revue de musique des universités canadiennes, 12(1), 52-74.

https://doi.org/10.7202/1014211ar

All Rights Reserved (C Canadian University Music Society / Société de musique des universités canadiennes, 1991
Ce document est protégé par la loi sur le droit d'auteur. L’utilisation des services d'Érudit (y compris la reproduction) est assujettie à sa politique d'utilisation que vous pouvez consulter en ligne.

https://apropos.erudit.org/fr/usagers/politique-dutilisation/ 


\section{POST-POSITIVISTIC EDUCATIONAL THOUGHT: IMPLICATIONS FOR NATURALISTIC RESEARCH METHODS IN SCHOOL MUSIC*}

\section{Carol E. Harris}

A decade has passed since Eisner $(1981 ; 1982)$ introduced the notion that an understanding of educational problems in the Fine Arts might be adversely affected by an overly-zealous adherence by researchers to the assumptions and techniques of natural science. One of the most problematic assumptions noted by Eisner was the positivistic position that considerations of fact alone are worthy of empirical inquiry. The dichotomy between facts and values, a hallmark of logical positivism, has dominated natural and social sciences during much of the 20 th Century (see, e.g., Garrison 1986:16,17; Schwandt 1990). Nor does the split enter as a stranger within the history of thought; since the time of Plato, people have distinguished rational thinking and its product "true knowledge" from the irrational and its products of confusion, superficial plausibility, and opinion (Egan 1987:445). Other polarized concepts, such as mind-body, adult-child, and civilized-savage, have arisen around this dichotomy.

Within educational thought, this inheritance may be seen in the conceptual division between cognitive and affective learning. The position, reflecting a split between thinking and feeling, has limited understanding of the very meanings held by people about music and about their own purposeful actions; it has, as well, contributed significantly to the downgrading of the Fine Arts within school curricula and award-granting agencies (Eisner 1981: 8, 9).

There are no tight boundaries around the concept of positivism for, as Garrison (1986) and Phillips (1983) note, there exist various branches of positivistic thought and considerable disagreement among proponents of each. Nevertheless, the term "positivism" is used widely to indicate the philosophy underlying the application of assumptions and methods of the physical and natural sciences to the realm of human affairs. I maintain that a philosophic stance underlies all

\footnotetext{
* The research on which this paper is based was partially funded by the Canadian Federation of University Women and by the SSHRC of Canada. Neither group is responsible for nor necessarily endorses this article's contents.
} 
research undertakings whether or not this stance is articulated. Moreover, I do not use the term "post-positivistic" as an indicator of positivism's demise; positivistically-driven premises dominate educational research in North America today. I focus here upon a philosophic position of modified relativism, variations of which have affected the course of educational research for 20 years in Europe and are now gaining credibility on this continent.

While many important advances have occurred in our understanding of music teaching and learning though experimental studies designed on a positivistic model, I argue in this paper that considerations of the meanings, beliefs, and attitudes that people attribute to school music programming also add significantly to our understanding of student learning. Furthermore, I hold that a Weltanschauung that perceives human activity as infinitely complex and variable, not governed by immutable and discoverable laws, is more closely attuned to the meaning of music than is its more positivistic counterpart.

To exemplify this position, I describe the methods followed during my own recent study (Harris 1991a; 1991b) which examines the supports and barriers surrounding school music programming in three Canadian school districts. This multi-case study focuses on the gap between curriculum planning and implementation and the particular role of technological rationality in creating and maintaining this gap. Through an examination of evidence gathered from those involved at the grass-roots of program planning and implementation, quite different assumptions about school music are revealed. These assumptions, in turn, affect the quality and even the provision of music education. In this paper, I refer to the conceptual and theoretical foundations of my study and the methods that emerged both from this framework and from observations in the field. From the findings, I extract a single theme to illustrate methodological points - the significance of early musical experience as this affects students within one school district.

\section{The Research Heritage}

Over the past four decades, school music research has been dominated by the techniques and assumptions of psychology where work in developmental and, latterly, cognitive fields has added to our understanding of the stages of human development and how humans process knowledge. Largely in quasiexperimental situations ${ }^{1}$, researchers replicate as far as possible conditions of the

\footnotetext{
${ }^{1}$ Exceptions to the experimental design, crucial to an understanding of child development, are found in the case-study observations of Piaget and his followers.
} 
laboratory. Their procedures involve the isolation, control, and manipulation of factors that may affect student learning, determinations of cause and effect, and predictions about the larger population (Erickson 1986: 126). The underlying assumptions for such procedures include the likelihood that data are viewed objectively by the researcher and that he or she is able to extract approximations of truth that may be extended to other times, places, and groups of people.

These assumptions are directly descendent from the 17 th century utilitarianism of René Descartes. In Descartes' sixth Discourse on Method, he notes with satisfaction

that it is possible to reach knowledge that will be of much utility ... and that instead of the speculative philosophy now taught in schools we can find a practical one by which knowing the nature of fire, water, air, stars, the heavens ... as well as we know the skills of our workers, we can employ these entities for all the purposes for which they are suited, and so make ourselves masters and possessors of nature (my emphasis added) (trans, in Berman 1984: 13).

This Cartesian statement of power and progress through a reasoned and systematic use of natural (and human) resources found resonance in an era dominated by magic, fortune, and authoritarian leadership. As pointed out by Berman (1984), the world was thus stripped of its enchantment and, as the centuries passed, factual happenings gained an ever-ascendent importance over the details of how people were affected and how they responded to these changes (also see, e.g., Culbertson, 1988; MacIntyre, 1984; and Sullivan, 1990).

From the application of assumptions about "scientific method" have emerged educational learning theories, especially in the developmental field, that have contributed greatly to educational progress within the music classroom. For example, teachers now have an expanded awareness of children's aural and oral capabilities at various ages and can, therefore, include classroom materials that present accessible vocal ranges and tonal patterns. As a finding that might well bear upon policy decisions, experimental research has provided evidence regarding musical aptitude which supports the provision of early childhood music programs (e.g., Gordon 1971).

It is in this larger area of program policy-making, however, that traditional research appears to have had little impact, either in official curriculum documents or in classroom practice. Despite a growing body of evidence supporting certain educational facts, there has been a reluctance on the part of policymakers, administrators and even teachers to implement program changes that 
reflect the findings of research (Carson 1986; Stenhouse 1978: 22). Studies by Hargreaves (1984) indicate that teachers, while aware of research findings, follow their own observations of classroom realities when making decisions. Elbaz (1991: 11) points out that the decision-making model upheld by psychology has been particularly inappropriate for the non-linearity and immediacy of teachers' tacit knowledge. Many agree that teacher-knowledge, largely ignored in experimental study during much of this century, offers invaluable information about the complex realities of learning (e.g., Butt and Raymond 1987: 66; Elbaz, 1991: 10; Hargreaves 1984: 65, 66). Others, recognizing the crucial role of administrators, have focused upon their actions and perspectives (e.g., Harris 1992). There appears to be a barrier erected by administrators and teachers between their knowledge of conventional research findings and the will to translate these findings into action; this occurs in school music programming as in other areas of the curriculum (Abeles 1984).

Barriers, however, are not uni-directional. Researchers, as well, have resisted accommodating the reality of practitioners. ${ }^{2}$ Although there has been a perceptible shift in paradigms within general educational research away from the manipulated experimental model to a more holistic empirical inquiry about the classroom and its inhabitants, this shift has not yet made an appreciable impact upon research in North American music education. ${ }^{3}$

Many possibilities exist as to why this may be so. Perhaps school music researchers, working mainly in music departments, have little contact with their fellow educators in other departments of education. Possibly those researching school music have more confidence in the IS-ness of reality than in the world of beliefs, attitudes, and values. Related to this possibility, Efland (1988) suggests that educators in the Fine Arts have been particularly eager to follow a mainstream approach to research and accountability in order "to bring credibility and validation to [their] neglected part of the curriculum". Still another possibility, raised in general curriculum theory, is that the qualitative work that has been produced has failed to impress other researchers with its logic, organization, and rigor (Macdonald \& Walker 1975: 3). In other words, existing qualitative work may have failed to convince. In light of the scarcity of such research within the field of school music, I consider the latter to be the most likely possibility.

${ }^{2}$ See, for example, Eisner (1988: 18) who contends that the dominant research language in education has "been one that has attempted to bifurcate the knower and the known".

${ }^{3}$ See, for example, publications of the Journal of Research in Music Education over the past five years. 
Having stated this challenge of credibility, I turn first to the conceptual framework and, then, to the methods that evolved during my own study. Unlike the reporting of many qualitative studies, I utilize to a great extent the vocabulary of experimental methods and thus attempt to lessen the linguistic gap between quantitative and qualitative approaches to empirically-based research. ${ }^{4}$ Specifically, I use aspects of my own work to exemplify what I consider to be the common purpose of empirical research, which is to demonstrate, through rigorous and systematic design and methods, both credibility and generalizability of findings. The differences in the two approaches lie, not only in the nature of the researcher's claims to truth and applicability, but in his or her view of reality and knowledge. ${ }^{5}$

\section{Theoretical Framework}

In conducting scientific investigation, whether in natural or social science, the researcher brings to the work an orientation or set of beliefs about the nature of reality and what constitutes knowledge about phenomena. This permits the researcher to establish priorities among the multitude of possible theories and approaches surrounding the object of investigation (see Kuhn 1962: 16, 17). I outline my approach to the problem at hand, first as a way of seeing the world and, then, within a framework of aesthetic and curricular theory.

In this study, schools and the programs designed, administered, and delivered within them - are treated as socially-constructed phenomena. That is, persons within schools bring with them the shared orientations of their society and, through their own words and actions, they maintain, modify, and change that society. These acts of construction or maintenance, however, do not proceed in a simple and uncontested manner, but as outcomes of struggles between social groups. The resulting organizational phenomena may be seen as facilitating the

\footnotetext{
${ }^{4}$ There will be two exceptions to this convention. The first inheres in my use of the first person, thus emphasizing full responsibility for my own research choices and interpretation (Eisner 1988b: 141; Greenfield 1984: 144-145; Van Leuen 1978). The second deviation from standard reporting involves the use of descriptors such as "actor", "respondent", "interviewee", or "key informant" in place of the customary "subject". This word choice indicates the interactive relationship between researcher and those persons within the context of investigation.

${ }^{5}$ See Smith and Heshusius (1986: 10) for a cogent re-working of the debate between objectivist and relativist philosophic positions although these authors erroneously limit the use of quantitative and qualitative research methods to these stances respectively. Greenfield (1991:10), on the other hand, clarifies the case for quantification or "getting the facts" as a possible step prior to a qualitative investigation of perceptions about beliefs, attitudes, and values.
} 
agency, or wishes, of certain groups and limiting that of others (Bates 1989: 16). These groups, some of which have great power while others have comparatively little, form social structures. The individual may be seen, therefore, both as acting upon his or her society and as acted upon by societal structures or collectives. This interaction between the individual and his or her social setting provides the ground for commonly-held assumptions and interpretations of meaning.

My own assumption is that, as participants share their perceptions of why they do what they do, action may be distinguished from automatic reaction, from behaviour, or from natural events. Therefore, I focus upon the meanings that people attribute to their actions as the backdrop to human understanding; I consider observable behaviour as a useful, though secondary, source of evidence.

\section{Aesthetic and Curricular Framework}

In further developing the lens through which I view programs within each Board, I draw upon writings in the aesthetics of music and upon curriculum and social theory. In examining human values and meaning about music, I support through the philosophy of music - aesthetics - the notion that cognition and affect, as inextricably linked phenomena, both constitute meaningful aspects of school programs.

The aesthetic argument may be summarized in these terms: while affect may be experienced by all persons at the elemental level, one's depth of response may increase as understanding (i.e., cognition) of music develops (Hanslick 1958: 11, 12, 101; Collingwood 1938: 26; Langer 1957: 73; Meyer 1956: 73; Sheppard 1987: 73). ${ }^{6}$ The premise guiding my observation of classes and the manner in which I interpret students' words, therefore, is that in the combination of feeling about music and its understanding, students are increasingly enabled to benefit from musical experiences throughout their lives. In short, my interpretation of words about music and my observation of classes were guided by indications of affective and cognitive student involvement.

From curriculum theory, at times general and at other times specific to school music, several issues emerge. One involves the conflict of values between those who espouse education for the personal growth of students and those who see it as preparation for the workplace (St.-John Brooks 1983). Another traces the

\footnotetext{
${ }^{6}$ Reimer (1989: 110) warns that increased perception merely sets the stage for a deepened aesthetic
} response; it makes such response possible though in no way inevitable. 
dichotomies that have arisen when people apply what has been called the "objective" scientific method to an understanding of human problems. For example, perceptions of a dichotomous position between affect and cognition can have a negative impact upon the Arts when artistic ways of knowing are discounted in favour of logical and analytical approaches (Eisner 1982: 37; Greene 1980: 20). Furthermore, there has been the suggestion that certain subjects of the school curriculum, not conducive to a right/wrong conclusion, are academically and politically suspect (Beyer 1983: 106, 107; Cornbleth 1987: 202); for this reason, the complexity and shades of meaning inherent in the Fine Arts place these subjects in jeopardy (Swanger 1983: 15-28).

In the 1950s, it was not surprising that music and other less secure subjects within the curriculum adopted the scientific or technological model. Arts educators, in a move to secure respectability, legitimacy, and funding, moved steadily towards a disciplined and structured approach to methodology and, later, a quantifiable means of accounting for their programs (Efland 1988). Although planning in the 1960s and 1970s involved composers, performers, musicologists, and music critics, practising music teachers were conspicuously absent. An outgrowth of planning that neglected the experiences of those at the "grass roots" of implementation led to the portrayal of music as a discipline that a) could be divided into pre-packaged segments for learning, and b) could be evaluated objectively. Moreover, the simplified division of learning into cognitive tasks, supplemented by records and prepared answer sheets, led to the assumption that teachers can simply teach anything, regardless of their personal knowledge (see Beyer 1983).

This has led to what some describe as a de-skilling process whereby complex jobs are broken down into specific actions with specified results so that less skilled and costly personnel can be used. When this "rationalization of labour" is applied to teaching, the de-skilled teacher must be re-educated or re-skilled in appropriate methods for using the new materials. One of the costs involved in this doubleforked process is the downgrading of teachers' professional work (Apple 1980: 15).

There are aspects of social theory as well that are applicable to my question. First is the suggestion that schools, rather than providing for an equalization of given class structures, actually exacerbate the differences. Theorists (e.g., Apple \& Beyer 1983; Anyon 1981) point out that schools - by sorting students at very early ages, by the expectations of teachers, and by materials used in the school - actually reproduce in children the work patterns and, therefore, the economic outcomes of their given social class. In the context of music programming, some sociologists argue that music programs are particularly elitist in that their content 
is slanted towards the perceptions and habits of the middle class and, thus, are far removed from the cultural capital that most students bring to school (Vulliamy $\&$ Shepherd 1984). Finally, as a further consideration regarding the elitist theme, Holmes (1985) suggests that unevenness in music programming (and physical education) in schools may be attributable to the availability of private tuition.

This theoretical foundation leads to the formulation of two specific questions: first, what are the effects of technological rationality on music programming and in what ways have programs become part of the dominant utilitarian ideology of our society; second, what assumptions and realities surround the topic of equality of educational opportunity?

\section{Selecting a Design Descriptor}

The explanatory lens described in the theoretical framework above-focusing as it does upon the beliefs, attitudes, and values of people - led to the choice of a qualitative study. Within the general rubric of "qualitative study", however, one finds specific research emphases such as ethnography (e.g., Schatzman \& Strauss 1973), phenomenology (S. Weber 1990), biography (Butt \& Raymond 1987; Elbaz 1991), and case study (Macdonald \& Walker 1975). While ethnography involves the researcher for extended periods of time in field observation and interaction, phenomenology directs the researcher towards a detailed examination and interpretation of meanings surrounding the object, concept, or situation under investigation. Biography, on the other hand, emphasizes the significance of the individual's observations and experience and the lessons that can be gleaned from these. Each of these methods emphasizes the dominant position of emergent theory, grounded in the experiences of those within the natural setting itself (Glaser \& Strauss 1967).

For my purposes, a multi-site case study seemed appropriate. The breadth and complexity of my question and the scarcity of research on the subject led me to cast a large investigative net and to develop a broad theoretical base before entering the field. This base, in turn, provided me with questions to investigate and a framework within which to interpret the data. I anticipated, however, that additional theory would emerge from the field and decided that the semistructured interview format, together with classroom observation, would allow for such new material. While there are no clear lines of demarcation among the various qualitative designs, the case-study provided both the structure and the flexibility which my questions demanded and allowed me, at the same time, to borrow from the traditions of ethnography, phenomenology, and biography. 


\section{The Design, an Anchor and Springboard}

My study led me to three Canadian school boards, selected on three criteria: a) that a music consultant, well-respected in the field, be present to act as my initial contact and possible key informant, b) that the sites be far removed, both geographically and in composition, from those known to me and, c) that the sites characterize a variety of approaches towards the planning and delivery of programs. The common thread linking these three Boards was that each operated from a Ministerial directive that classroom teachers maintain responsibility for music in the elementary grades.

Within each board, I interviewed and recorded the words of approximately 40 persons including administrators, guidance counsellors, music teachers ${ }^{7}$, high school students, and parents. Administrator and teacher interviewees were initially identified by the District consultant. Teachers, in turn, directed me toward student interviewees who would represent (at my request) "a crosssection of social and economic levels". As well, I observed classes and rehearsals, reviewed pertinent curriculum and policy documents, and attended school and community musical performances.

As the analysis of data begins on day one of the naturalistic investigation, design methods tend to change and evolve as research progresses (Bogdan \& Biklen 1982: 55-70; Schatzmann \& Strauss 1973: vii, 7). Thus in my study there occurred some "snowballing" of interviews (McMillan \& Schumacher 1989: 183-184) where one teacher directed me to other interviewees. Moreover, once within high schools, I had to search for additional students from the lower socioeconomic bracket. Teachers, disregarding my request for heterogeneous representation, tended to select interviewees of solid middle-class origins. There were occasions, as well, where evidence from the field sent me back to theory encountered earlier in my preparatory reading. In this way, the road between research findings and theory remained open (Hodgkinson 1986: 15; Meek 1987: 197,200 ) for the duration of the study. Nor did this interactive process culminate with the first draft of the report. A most important step of validation involves checking one's description with key actors. In this way, the researcher clarifies, corrects, and modifies his or her understanding of the situation. ${ }^{8}$ In my study,

${ }^{7}$ I interviewed both classroom teachers and music specialists. The latter I define as teachers who have at least one year of pedagogical training in music and who spend at least $50 \%$ of their time in the specialist area.

${ }^{8}$ See Weber's (1971) description of Verstehen which emphasizes the researcher's responsibility to understand events from the actors' perspective; also see Stenhouse (1978) who writes that the casestudy develops a "theory of action as it is experienced, not simply a theory of behaviour" (my emphasis added). 
these checks constituted a penultimate step, immediately prior to writing the final report.

\section{Selected Findings}

\section{Providing for the Early Years}

A major divergence among the three school Boards occurred in their interpretation of Ministry directives regarding primary and elementary programming. The two Ministries involved, British Columbia and Ontario, recommend that children learn to utilize the symbol system of music, that is, learn to read and write music. This recommendation, however, is juxtaposed with the unqualified statement that "responsibility for the teaching of art programs ... rests primarily with the classroom or generalist teacher" (Ontario 1984). The Ontario directive then becomes more descriptive and reports that "[s]ome boards have provided additional support ... through a network of consultants, itinerant teachers ... or staff members with additional qualifications of expertise". These vague guidelines for program implementation encourage the assumption by Board level decision-makers that a teacher can teach anything, given appropriate technological aids and expert guidance (see Arendt 1968: 182). Teaching here is viewed as a "process", with little regard given to the teacher's specific knowledge base an approach identified by Holmes (1991) as "progressive" and a therapeutic form of technological rationality.

The Ministry description, however, represents programming practice in the Ontario District of Leicester. ${ }^{9}$ Three features concerning Leicester's programming for the early years emerge from the evidence - first, that classroom teachers, even though provided with the supports listed above, are unable to provide for the musical development of their students; second, that school administrators and consultants from Central Office, while quite articulate about the differences between performance goals and those of musical literacy, accept the former - albeit often unwillingly - as "music". The third feature surrounds the highly contentious nature of programming for young children with a dissonance of perceptions between decision-makers and those who must make these decisions "operational". While principals frequently highlight their schools' successful classes and extra-curricular activities, they recognize serious problems in the overall system and agree with teachers, Board consultants and, occasionally, parents who express frustration that young children are receiving

${ }^{9}$ Apart from the location of Districts by Province, pseudonyms are used to protect the identity of people and places. 
little or no training. Teacher Richards, for example, registers her children privately because they have "no music in their classrooms". In her son's school, "there is only a retired music teacher who comes in to do the choir". Mrs. Richards' experience finds resonance in these comments by others in similar circumstances:

My son is seven years old in grade 2 and, for the last two years, there has been no scheduled music. They have an itinerant teacher who comes in from the Board and it's his favorite class of the month. But it only happens once a month! (High School Teacher Mrs. Collins).

My own children had limited experiences in school. Of course they had private lessons on piano ... . We always sang in the family but, in school, I was never happy with any music that they had. It was weak, very weak ... those who can speak out can pay ... and they find an alternative (Principal Thomas).

In the last province where we lived, my daughters had classroom music, two choirs and strings. When they started here ... teaching was very spasmodic, according to the whim of the teacher. [The girls] joined the Board Choir and learned most of their music through private teachers (Consultant Mrs. Lockyer).

The Leicester Board, in fact, subsidizes alternative music programs for families that have the finances and time to allow participation. First, there are the flourishing "After School Programs" where private teachers offer classes in such areas as Kodaly, Orff, recorder, and piano. Centrally located Board choirs provide the second alternative venue for musical training.

Perhaps it is not surprising that some parents and Board personnel express the belief that those "interested" and "talented" in music will avail themselves of these alternatives. My data, drawing upon the words of principals and teachers in economically disadvantaged areas of town, however, point to quite different definitions of "interest" and "talent". For example, many children perceived by Principal Roberts to be highly motivated in his school, come from homes where parents face the choice "between paying a fee for a musical activity and skipping a few meals at the end of the month". Nor does the Board's willingness to pay for those "in need" find any takers here; for one thing, as Principal Roberts points out, a free bus fare does nothing to alleviate the dangers that children face as they return home by bus after dark in this neighbourhood.

Leicester presents a pristine example of the divergence of musical opportunities among children of differing socio-economic backgrounds. Simply put, many 
middle-class children have private lessons (see Holmes 1985: 24) and thus gain access to some musical training while poor children have little positive exposure during the years considered to be most vital to their developing musical aptitudes (Gordon 1971: 7). While sites of musical excellence do exist at elementary levels, the odds against children receiving a sequenced and balanced program in Leicester are strong. Two consultants travel among the 50 English-language schools; at the time of my study, classroom teachers in these schools could expect visits from consultants on a fortnightly basis every second year. Within schools, teachers with musical expertise and pedagogical training, at best, teach their own class and one or two others. Students, therefore, totally lack continuity of programming. Moreover, as Mrs. Lockyer explains, the Board's music curriculum "has been designed more for the teachers' abilities than for the children".

Without continuity, children reach intermediate grade levels with low selfconfidence in music and a reluctance to participate in music. Teacher Mrs. Standish compares her experiences with the psychological readiness of intermediate students as they emerged from continuous and discontinuous programs:

There were enormous differences. The classes where I had been able to provide some musical education the year before were much more enthusiastic as they came into grades 4,5 , or 6 . Grade $6 \mathrm{~s}$, for instance, that had not had music in grade 5 were unmotivated and difficult to interest ... their selfconcept as musicians was low. Essentially, none had ever been developed. To take a 12-year-old child who's not willing to risk too much and try to get him doing any sightreading or rhythmic exercises is a super challenge.

The experiences of Mrs. Lockyer at Board level coincide with those of Mrs. Standish. Speaking of her days in the classroom, she mentions the difficulty of "winning over" students at the grade 7 level who enter with no music background, "whereas, the ones I had all along, who knew [music] and had continuous music education - no problem".

\section{Technological Thought and Action}

The recollections of students about their early schooling confirm this scenario. All students spoke of discontinuous programs; many mentioned that they neither learned to read nor write in elementary school and a few described their programs as "sing-alongs" with records. Vivian, a 20-year-old who now teaches music part-time to eager pre-schoolers, brings us to the theme of technological thought and action as she ponders the question of why music is not provided for children in the primary grades: 
I guess a lot of people just feel that younger people aren't capable of learning [music]. Or they want quick results, and a 6-year-old is not going to learn how to play something as quickly as a 12 -year-old.

The choices made by Board personnel frequently reap not only intended, but unintended, consequences. Vivian's words illustrate the modern insistence upon efficiency and effectiveness. Vivian recognizes that results will be produced with greater immediacy if musical resources are applied at secondary levels of schooling. She also realizes that immediate results influence decision-makers, despite the evidence of the benefits of musical training during children's early years. In the efficiency-effectiveness equation, the former consideration often assumes precedence. Efficiency can more easily be quantified in an input-output framework, whereas considerations of effectiveness bear long-term implications. Moreover, effectiveness is often incorrectly considered synonymously with efficiency as "immediate effect".

To place this in the school music context, the input of one teacher and $x$ dollars in band equipment may yield, in a single year, recognizable music selections for the entire community's enjoyment. In contrast, the application of one teaching unit to a primary-elementary school brings benefits that only sophisticated psychological testing of student aptitude and achievement and qualitative studies can begin to reveal. ${ }^{10}$ Observable outputs of a more subtle nature, however, may be detected in the children's choir, new playground games, and songs heard in the home and school corridor. It is obvious to Vivian that her Board has chosen the route that produces immediate and less subtle results.

Although my study presents considerable evidence that the rationalization occurring at school board levels does not lead to the de-valuation of music, ${ }^{11}$ another possible outcome of rational thinking occurs. As described by Wise (1979: 59), we see a reduction in goals whereby the purposes of education are narrowed so that "what we strive to accomplish becomes minimal and quite selective". This reductionism is evident in Leicester where the curriculum is designed to match the capabilities of teachers rather than those of children. Furthermore, it is conceivable that an entire subject area may be valued more for its effect on the community than for its inherent benefits to students (Apple 1980: 57). When this occurs, the visible outcomes, perceived to be an efficient and effective return on dollars expended - for the purchase of instruments, for

${ }^{10}$ In all three Boards of my study, the provision of teachers knowledgeable in the subject area of music could be guaranteed only at secondary levels.

${ }^{11}$ I point out that the children of decision-makers in my interview sample study music. 
example - take precedence over student learning and, this study would indicate, over the values of those involved in music education.

\section{Summary of Methodology and Discussion}

Using this single issue of early childhood training, drawn from only one site, Leicester, we may trace the features of qualitative research that were outlined above and which render the study both believable and useful. First appears the description of music programming in Leicester. This includes the closest approximation to "the facts" found in the study - statements of policy and implementation and a review of who actually present music to which children. A more interpretive description of events and conditions occurs as participants reveal their attitudes towards the situation, their beliefs about the wisdom of present decisions, and their recommendations for change. These attitudes and beliefs rest upon the explicit and tacit understanding people possess about the way children learn and the choices they ought to be able to make. The facts, in this way, are inextricably linked with values held.

Then a second level of interpretation takes place as I, the researcher, place events and the perceptions of others in the context of existing theory. What segments of my theoretical framework apply to these fragments of data concerning the issue at hand - early musical opportunity? The most apparent explanation of why things are the way they are stems from the notion that private lessons fill the need for tuition in the arts. ${ }^{12}$ In Leicester we see that, while children of decision makers and other members of the more affluent classes receive private tuition, many children do not.

Bourdieu $(1974: 37,38)$ has pointed out that, in order to assure inequality of educational opportunity, we in schools have only to treat children equally. In the case of music programming in Leicester, the treatment of students is far from equal. The alternatives, particularly the After School Program, secure differing musical opportunities for the economically well-to-do and the poor. By staffing elementary schools with little regard for musical strength, those inequalities inherent in the community and exacerbated by the After School Program and District Choir are further reinforced.

As students reach high school levels, the differentiation appears in the eyes of many administrators and teachers and, one may assume, of the general public,

12 Evidence from another site indicates, however, that private lessons are no substitute for school music programs that provide for the development of skills such as singing, movement, improvisation, composition, and the physical coordination used in musical games and dances. 
to be the natural outcome of "talent" dispersement. In this way, the myth is perpetuated that musical talent and academic achievement go together "hand-inglove". While this myth has a factual basis, as do most myths, the strong possibility exists that students who achieve less academically may be musically gifted as well. Present programming in Leicester, however, precludes an investigation of this possibility.

Also in Leicester we see an application of the technological model of curriculum programming (Beyer 1983; Efland 1988) whereby pre-packaged materials in the form of books and records prepared far from the point of application are assumed to provide for the needs of teachers untrained in music. A process of teacher deskilling occurs without, unfortunately, the requisite re-skilling in terms of knowledge and ability to use the new materials. ${ }^{13}$

In this one case, clear lines of social reproduction appear. Children who enjoy early opportunities tend to find themselves in the band and choral seats of secondary music performance groups. These children also reap the benefits of what Hamblen (1990) calls "cash literacy" or what Hirsch (1987) in somewhat reductionist terms refers to as "what every American should know about the arts". Both Hamblen and Hirsch speak of the cultural or artistic knowledge that allows those who possess it to hold a more secure portion of society's benefits.

From the above description and interpretation, both of methods and of selected findings, we may look for links between the significance of research as known to us through experimental studies and those of a qualitative approach. Specifically, how well can concepts of validity, generalizability, and reliability be applied to the newer approach and, moreover, should these concepts be used in the new context? To address the questions in reverse order, Ihold that the familiar concepts, especially the former two, must remain goals of all research. Qualifications apply, however, to the way these terms become meaningful for those operating within the ontological and epistemological paradigms of positivism and post-positivism. There is no need to review here the connotations for these three terms as they have been applied and continue to be used by researchers of a positivistic persuasion. Within a more phenomenological or naturalistic framework, however, the terms lose their causal and predictive properties and assume more contextual usage.

In naturalistic inquiry, for example, the generalizability or applicability of one case to another is carried out by the reader and not by the researcher. Although

${ }^{13}$ In the two other sites, considerable efforts are made to develop appropriate skills in pedagogy for those teachers who already have backgrounds in music performance. 
the researcher identifies, describes, and interprets salient features of the original case in context, these features are later decontextualized for use in other situations (Marton 1988: 182). This occurs, Meek (1987) suggests, where features of one set of experiences overlap with those of the reader (also see Tripp 1985: 34).

As most Provincial Ministries in Canada - apart from three in Atlantic Canada - recommend implementation practices that, in Apple's terms, would demand varying degrees of "de-skilling", it is reasonable to expect that features described in this paper will correspond with conditions in many other school districts. Moreover, readers may sense a dissonance between elements of their own situation and the values they hold toward the inclusion of the Fine Arts in educating the whole child, i.e., between theory and practice. While my study will not prescribe a "cure" for the reader's situation it will, I trust, broaden the options available for those who seek to narrow the gap between existing programs and their sense of how things ought to be.

For those within the site under discussion, the research may fulfil two roles. First, participants, though articulating aspects of their programs, make many tacit understandings conscious. As Gronn (1984) has explained, subjective clarification occurs though the very process of finding the words to describe our story. Furthermore, those within the site may come to a greater understanding of what is happening as they reflect upon the stories of others. The whole may clarify, in this way, the particular.

Some qualitative researchers hold that the very concept of reliability - that is, the possibility of replicating a study - is inimical to the relativist view of reality. In the broad sense, of course this is true for, as Meek (1987: 199) states, a second researcher's results would approximate the first only if the same theoretical framework were used and the same general problems identified. This would rarely, if ever, occur. On the other hand, Marton (1988: 183) focuses upon the concepts that are found through qualitative inquiry as reliable or replicable features. He distinguishes between 1, the finding of a certain conception, a form of thought and 2, the question of whether others can find this concept in reality once it has been identified and described. While the first constitutes an act of discovery and, as such, does not demand replication, duplication of the second is reasonable to expect. Once categories have been found, "it should be possible to reach a high degree of intersubjective agreement concerning their presence or absence if other researchers are to be able to use them" (ibid.: 183). What is important in secondary case studies, of course, is that the discovered phenomena, once named, can be recognized in their new context. This recognition is seen by 
the naturalistic inquirer as being of far greater significance than would be a numerical count of the phenomenon's occurrence. In the case of Leicester, for example, another researcher should be able to trace technologically-based decisions with great alacrity.

We should remember, however, that the salient features of one case may not be those of another. Therefore, researchers who attempt to report one case in light of another's salient features may pose for themselves insurmountably artificial situations. This in no way precludes the researcher from comparing one case with another. Let us take the case of Leicester again. Here one of the salient features involves participants' perceptions about the way young children are denied exposure to musical experiences. Although a uniform picture of musical deprivation emerges from the words of teachers, Board personnel, principals, parents and older students in Leicester, in the two other sites a different situation occurs. In the latter two Boards, the provision of continuous and sequential musical learning for primary children was an objective accepted by all, although one Board achieved this goal with far greater success than did the other. In Leicester, the urgently expressed need for early education takes precedence in my report. In the other sites, descriptions of early childhood music tend to emphasize successful teaching strategies and Board initiatives that support teachers' work.

The researcher follows several steps in establishing the validity of his or her work, some within the study's design and others of a descriptive and interpretive nature. The first lies in a triangulation of data; this, in my case, involved discerning patterns and unique features among the viewpoints of different cohorts of interviewees, records of classroom observations, and official policy statements. The researcher's interpretation must demonstrate consistency with the evidence and relate either positively or negatively with existing theory. A sort of face validity concerning the actual contents of taped interviews, furthermore, may be validated by others - for student researchers, by their committee members and, for the established researcher, by collaborators in the research enterprise.

Perhaps the most significant validation, from the researcher's perspective, comes as she checks descriptions of conversations and events with the study's participants. This holding up of the mirror of socially-constructed reality becomes a sensitive issue when the reflection is problematic. The case of Leicester exemplifies this as my portrait points to the large gap between expressed values and school practice and where instances of educational inequalities fairly leap from the pages of the report. In my experience, however, participants - even in such cases - tend to weigh evidence fairly in the light of 
their personal experiences and observations. Thus my interpretation of Leicester was returned with these words penned by a major participant: "Sadly, your report seems to accurately reflect conditions here". Although the qualitative researcher may outline the steps s/he follows in establishing the truthfulness of the record, the final test of credibility rests with the reader. The reader must be convinced in light of his or her own personal knowledge and experience.

The methods outlined above provide merely the stepping stones that worked for me as I carried out my study. These stones, which rest on an extensive and eclectic theoretical bed, are formed from the rich description of those who construct reality in their respective sites and from my interpretation of assumptions underlying this reality. Together, the stones pave the way for an extension of the research to other times and places. The nature of this extension will change from site to site in context with readers' perceptions of educational need.

\section{REFERENCES}

ABELES, H.F., HOFFER, C.R., and KLOTMAN, R.H.

1984: Foundations of Music Education. New York: Schirmer.

ANYON, J.

1981: “Social Class and School Knowledge," Curriculum Inquiry, 11/1: 3-42.

APPLE, M.W. and BEYER, L.E.

1983: "Social Evaluation of Curriculum," Educational Evaluation and Policy Analysis, 5/4: 425-434.

APPLE, M.W.

1980a: "Curricular Form and the Logic of Technical Control: Building the Possessive Individual," in Barton, L., Meighan, R., and Walker, S. (Eds.), Schooling Ideology, and the Curriculum. London: Falmer.

1980b: "Analyzing Determinations: Understanding and Evaluating the Production of Social Outcomes in Schools," Curriculum Inquiry, 10/1: 55-76.

ARENDT, $\mathrm{H}$.

1968: Between Past and Future: Eight Exercises in Political Thought. Markham, Ontario: Penguin.

BATES, $R$.

1989: "Is There a New Paradigm in Educational Administration?," unpublished paper, Victoria, Australia: Deakin University.

BERGER, P. and LUCKMANN, T.

1967: The Social Construction of Reality: A Treatise in the Sociology of Knowledge. Toronto: Anchor Books. 
BERMAN, $M$.

1984: The Reenchantment of the World. Toronto: Bantam Books.

BEYER, L.E. and APPLE, M.W.

1988: The Curriculum: Problems, Politics, and Possibilities. Albany: State University of New York Press.

BEYER, L.E.

1983: "Aesthetic Curriculum and Cultural Reproduction," in Apple, M.W. and Weis, L., Ideology and Practice in Schooling, Chapter 4. Philadelphia: Temple University Press.

BOGDAN, R.C. and BIKLEN, S.K.

1982: Qualitative Research for Education: An Introduction to Theory and Methods. Boston: Allyn and Bacon.

BOURDIEU, $P$.

1974: "The School as a Conservative Force: Scholastic and Cultural Inequalities," in Eggleston, J. (ed.), Contemporary Research in the Sociology of Education. London: Methuen.

BUTT, R.L. and RAYMOND, D.

1987: "Arguments for Using Qualitative Approaches in Understanding Teacher Thinking: The Case for Biography," Curriculum Theory, 7/1: 62-93.

CARSON, T.R.

1986: "Closing the Gap Between Research and Practice: Conversation as a Mode of Doing Research," Phenomenology and Pedagogy, 4/2: 73-85.

COLLINGWOOD, R.G.

1958: The Principles of Art. London: Oxford University Press.

CORNBLETH, C.

1987: "The Persistence of Myth in Teacher Education and Teaching," in T.S. Popkewitz (ed.), Critical Studies in Teacher Education. New York: Falmer Press.

\section{CULBERTSON, J.A.}

1988: “A Century's Quest for a Knowledge Base," in N.J. Boyan (ed.), Handbook of Research on Educational Administration: A Project of the American Educational Research Association. New York: Longman.

EFLAND, A.D.

1988: "The Arts and Physical Education in General Education: A Cononical Interpretation," in I. Westbury and A.C. Purves (eds.), Cultural Literacy and the Idea of General Education: Eighty Seventh Yearbook of the National Society for the Study of Education, Part 2. University of Chicago Press. 
EGAN, $\mathrm{K}$.

1987: "Literacy and the Oral Foundations of Education," Harvard Educational Review, 57/4: 445-472.

EISNER, E.

1988: "The Primacy of Experience and the Politics of Method," Educational Researcher, 17/5: 15-20.

1982: Cognition and Curriculum: A Basisfor Deciding What to Teach. New York: Longman.

1981: "The Role of the Arts in Cognition and Curriculum," Canadian Music Educator, 23/1: 7-19.

ELBAZ, F.

1991: “Research on Teachers' Knowledge: The Evolution of a Discourse," Journal of Curriculum Studies, 23/1: 1-19.

\section{ERICKSON, F.}

1986: "Qualitative Methods in Research on Teaching," in Wittrock, M.C. (Ed.), Handbook of Research on Teaching, 3rd Ed., New York: Macmillan.

GARRISON, J.W.

1986: "Some Principles of a Post-Positivistic Philosophy of Science," Educational Researcher, 29/2: 12-18.

GLASER, B. \& STRAUSS, A.L.

1967: The discovery of grounded theory: Strategies for qualitative research. Chicago: Aldine.

GORDON, E.

1971: The Psychology of Music Teaching. Englewood Cliffs: Prentice-Hall.

GREENE, $M$.

1980: Breaking Through the Ordinary: The Arts and Future Possibility," Journal of Education (Boston), 162/3: 18-26.

\section{GREENFIELD, T.B.}

1991: "Re-forming and Re-valuing Educational Administration: Whence and When Cometh the Phoenix?," Organizational Theory Dialogue, March.

1984: "Leadership and Schools: Willfulness and Nonnatural Order in Organizations," in T.J. Sergiovanni and J.E. Corbally (eds.), Leadership and Organizational Culture. Chicago: University of Illinois Press.

GRONN, P.C.

1983: "Talk as the Work: The Accomplishment of School Administration," Administrative Science Quarterly, 28: 1-21. 
HAMBLEN, $\mathrm{K}$.

1990: "Beyond the Aesthetic of Cash-Culture Literacy," Studies in Art Education: A Journal of Issues and Research, 31/4: 216-225.

HANSLICK, E.

1957: The Beautiful in Music, M. Weitz and G. Cohen (Trs.). New York: Liberal Arts Press.

HARGREAVES, A.

1984: "The Significance of Class Strategies," in Classrooms and Staffrooms: The Sociology of Teachers and Teaching, A. Hargreaves and P. Woods (eds.). Open University Press.

\section{HARRIS}

1991a: Administering School Music in Three Canadian Settings: Philosophy, Action, and Educational Policy. Unpublished doctoral dissertation, University of Toronto.

1991b: "Philosophy, Action, and Educational Policy in the Administration of School Music: An Overview," Canadian Association for Studies in Educational Administration Newsletter, 20/1: 26-31.

1992: "Policy and Practice in School Music Programs," The Canadian School Executive, 12/1: 27-31.

\section{HIRSCH, E.D.}

1987: Cultural Literacy: What Every American Needs to Know. Boston: Houghton Mifflin.

\section{HODGKINSON, C.}

1986: "New Directions for Research and Leadership: The Triplex Value Bases of Organization Theory and Administration," Journal of Educational Administration and Foundations, 1/1: 4-15.

\section{HOLMES, M}

1985: "The Secondary School in Contemporary Western Society: Constraints, Imperatives, and Prospects," Curriculum Inquiry, 15/1: 7-36.

\section{KUHN, T.}

1970: The Structure of Scientific Revolutions. Chicago: University of Chicago Press.

\section{LANGER, S.K.}

1957: Problems of Art: Ten Philosophical Lectures. New York: Scribner's Sons.

MACDONALD, B. and WALKER, $R$.

1975: "Case-study and the Social Philosophy of Educational Research," Cambridge Journal of Education, 5/1: 2-11. 
MACINTYRE, A.

1984: After Virtue, 2nd Edition. Indiana: University of Notre Dame Press.

MARTON, F.

1988: "Phenomenology: Exploring Different Conceptions of Reality," in D.M. Fetterman (ed.), Qualitative Approaches to Evaluation in Education: The Silent Revolution. New York: Praeger.

MCMILLAN, J.H. and SCHUMACHER, S.

1989: Research in Education: A Conceptual Introduction, 2nd Edition. London: Scott, Foresman.

MEEK, V.L.

1987: "The Coalface Revisited," in R.J.S. MacPherson (ed.), Ways and Meanings of Research in Educational Administration. Armidale, NSW: University of New England.

MEYER, L.

1956: Emotion and Meaning in Music. University of Chicago Press.

ONTARIO

1984: The Arts: Ontario Schools, Discussion Paper. Toronto: Ministry of Education.

PHILLIPS, D.C.

1983: "After the Wake: Postpositivistic Educational Thought." Educational Researcher, May: 4-12.

REIMER, B.

1989: A Philosophy of Music Education, 2ndEdition. Englewood Cliffs: PrenticeHall.

SCHATZMAN, L. and STRAUSS, A.L.

1973: Field Research: Strategies for a Natural Sociology. Englewood Cliffs: Prentice-Hall.

SHEPPARD, A.

1987: Aesthetics: An Introduction to the Philosophy of Art. Oxford University Press.

SMITH, J.K. and HESHUSIUS, L.

1986: "Closing Down the Conversation: The End of the Quantitative-Qualitative Debate Among Educational Inquiries," Educational Researcher,15/1:4-12.

SULLIVAN, E.

1990: Critical Psychology and Pedagogy: Interpretation of the Personal World. Toronto: O.I.S.E. Press. 
STAKE, R.E.

1985: "The Case Study Method in Social Inquiry," Educational Researcher, 7/2: 5-8.

ST.-JOHN BROOKS, C.

1983: "English: A Curriculum for Personal Development," in M. Hammersley and A. Hargreaves (eds.), Curriculum Practice: Some Sociological Case Studies. New York: Falmer Press.

SCHWANDT, T.A.

1990: "On Methodology and Moral Inquiry or What's Going on Here?," Organizational Theory Dialogue, July: 1-7.

SWANGER, D.

1983: "The Future of Aesthetic Education," Journal of Aesthetic Education, 17/1: 15-30.

TRIPP, D.H.

1985: "Case Study Generalizations: An Agenda for Action," Primary Education Research Journal, 11/1: 33-43.

VAN LEUEN, M.C.

1978: "Scholarship: A Singular Notion," The Atlantic, 241/5: 88-90.

VULLIAMY, G. and SHEPHERD, J.

1984: "A Comparative Sociology of School Knowledge," British Journal of Sociology of Education, 4/1: 3-16.

WEBER, $M$.

1971: Max Weber. J.E.T. Eldridge (Ed.). London: Thomas Nelson.

WEBER, $S$.

1990: "The Teacher Educator's Experience: Cultural Generativity and Duality of Commitment," Curriculum Theory, 20/2, 141-159.

WISE, A.E.

1979: Legislated Learning: The Bureaucratization of the American Classroom. University of California Press. 